\title{
INFLUENCE ANALYSIS OF REWARDS \& MOTIVATION, COMMUNICATION, DEVELOPMENT, SUPPORT SYSTEM, EMPLOYEE SELECTION, EMPLOYEE RECRUITMENT, AND HEALTHY WORK ENVIRONMENT ON INTERNAL MARKETING (CASE STUDY AT PORT DIVISION BONTANG COAL TERMINAL PT INDOMINCO MANDIRI)
}

\author{
Syahidul $^{1)}$, Gusti Noorlitaria Achmad ${ }^{2)}$, Syarifah Hudayah ${ }^{3)}$ \\ Faculty of Economics and Business, University of Mulawarman ${ }^{1), 2), 3)}$ \\ E-mail: syahidul.syah@gmail.com, gusti.noorlitaria.achmad@feb.unmul.ac.id, \\ syarifah.hudayah@feb.unmul.ac.id
}

\begin{abstract}
:
Internal Marketing is the important aspect in the organization to measure business performance. The job of internal marketing is to recruit, train and motivate employees who can serve customers well. Without being actively promoted, internal marketing can have a negative impact on service quality, which can lead to decreased customer satisfaction and profitability. This study is focused on the services division especially in port division Bontang Coal Terminal PT IMM. Researchers took research data through a Google Form questionnaire. For testing the hypotheses researcher used the 84 respondents. There are 7 indicators used to assess internal marketing. To test the level of validity and reliability used PASW Statistics 18, and to test the results of the hypothesis used SEM PLS to determine the relationship between variables. The findings of this study are that the Rewards and Motivation, Communication, Development, Support System, Employee Selection, Employee Recruitment, and Healthy Work Environment have positive significant on Internal Marketing.
\end{abstract}

Keywords: Internal marketing, services, customer satisfaction

\section{Introduction}

The demand for coal has decreased in line with the global economic slowdown. Many factors have contributed to the decline in coal demand, apart from the economic slowdown. This decrease has an impact on business work that must be adjusted to economic conditions, such as production must be efficient in carrying out mining, coal supplies, storage of production, shipping operations must also be as effective as possible, and maximize the role of internal like internal marketing in order the employees able to serve customers well so that they can create customer satisfaction. Marketing activities within the company can be as important as activities outside the company. Elsamen \& Alshurideh (2012) suggest internal marketing, a dimension which includes rewards and motivation, effective communication, effective employee selection, effective recruitment, effective development, support system, healthy work environment. Based on these conditions, in this study meant that the internal marketing is an effort to provide the best service to internal customers (employees) in order the dedicated employees motivated so that they can provide the best service to customers.

\section{Internal Marketing}

There are a lot of definitions of marketing that explained by expert like P Kotler \& Armstrong (2008) say that marketing is satisfying customer needs and according to Philip Kotler \& Keller 
(2009), marketing is a social activity and an arrangement. Marketing is having an important role for company because marketing has a function to find, get, retain, and multiply consumers and dominate the market. Especially in internal marketing employees play a major role in services (Chun-Cheng \& Hung, 2008). Internal marketing can have a negative impact on service quality, which can lead to decreased customer satisfaction and profitability. It has been suggested that internal marketing to provide the best service to them (Ting, 2011). Internal Marketing Orientation is an important concept which will affect business performance (Sarker \& Ashrafi, 2018). Internal market is the best thinking and motivation of employees and a performanceoriented approach to customers (Gronroos, 1994). The purpose of internal marketing activities is to improve the quality of relationships with external marketing (Ballantyne, 2004). Kumar (2010) also argues that internal marketing is a very significant aspect of service marketing activities.

\section{Rewards and Motivation}

Motivation refers to the process by which a person's efforts are energized, directed, and maintained to achieve goals (Robbins \& Coulter, 2018). Companies must be able to manage a system of motivation and rewards for employees so that the company gets the advantage of the competitive work of all employees. The most difficult challenges is how to make managers distinguish the good, average, and bad performers (Raymond et al., 2016).

Many organizations today recognize that motivating employees also requires a degree of respect between management and workers. This respect can be as involving employees in decisions that affect them, listening to employees, and implementing their suggestions where appropriate (DeCenzo \& Robbins, 2009). Tansey, L., McHugh, E. and McGrath (2004) discuss ways in which management can use internal marketing to motivate employees to provide the best possible service to customers.

\section{Communication}

The term communication is used freely by all people in modern society, including members of the public, organizational behavior experts, and management practitioners (Luthans, 2009). To form an effective communication, how the management create the communication in service organizations" (Lovelock \& Wright, 2000). Organizations are required to improve communication with their employees so that their vision and mission are conveyed and then provide effective strategies for transferring knowledge and information (Roberts-lombard, 2010). Effective internal communication can create tools that can assist management in measuring the level of satisfaction so as to build trust, respect and employee loyalty (Lovelock \& Wright, 2000).

\section{Development}

Employees must get training for development so that the tasks given can be completed properly in accordance with organizational goals (Piercy, 1991). Self-development of employees is also an effective part of employee development (Tony \& Ioanna, 2003), self-development giving authority and enabling employees to act, behave, think and make decisions to get a job faster and easier (Kaner et al., 2007). It depends how to providing them with the resources they need to use their own discretion confidently and effectively to take on new responsibilities (Lovelock \& Wright, 2000). Organizational support can create quicker action in organizing (Gronroos, 1994). This can impact with the employees to choose various career paths, according to Larsson et al., 
(2007) not everyone is suitable to lead a career that is oriented towards power and wealth, in this study identified four different paths that generally correspond to several types, namely: first, pathways. career expert: maintain current position through quality improvement and consolidation. Second, linear career path: the increase in employees in an organization until they reach the top of the hierarchy. Third, the spiral career path: related diversification through new applications of core competencies motivated by personal learning and growth. Fourth, transitory: this new opportunity target is motivated by variety and novelty which has a performance appraisal factor of speed, flexibility, opportunity, recognition.

\section{Support System}

Technology is a tool to developing organizational performance and accelerating internal processes. The opinion of Pugh et al., (2002) said that the information system can makes service delivery easier. Pride (2000) that the main role of the marketing system is how to retrieve and store data with using new technologies such as the internet, voice over IP (VoIP), cell phones and video conferencing to help employees and teams interacting. Support technology will help the organization to work more efficiently and effectively.

\section{Employee Selection}

Choosing a workforce is not an easy job to do if only knowing the physical condition of an applicant is still an easy job, but to find out their psychological abilities is very difficult to measure, therefore success in selecting human resources will greatly help the progress of an organization (Simamora, 2006). Armstrong (2006) states that selecting candidates starts from screening applications, interviews, testing, assessing candidates, assessing the results, offering jobs, getting references, then preparing work contracts. Therefore, that managers have an important function in selecting employees who are in accordance with the characteristics of the task to be carried out, this is done so that superiors can easily manage their employees. (DeCenzo \& Robbins, 2009). To help the organization performance, management must select employees according to the job skills they are looking for so that they can create jobs effectively in the future (Burke \& Wilcox, 2006).

\section{Employee Recruitment}

Quoting several expert opinions which state that recruitment is very important in human resource management activities because according to Ardana (2011) the quality of human resources depends on the quality of recruitment. It is further said that recruitment is a follow-up to the first management function, namely the procurement of labor. Recruitment is furthermore a series of activities to find and attract job applicants with the motivation, abilities, skills, and knowledge needed to cover the deficiencies identified in staffing planning. Thus, recruitment aims to find qualified applicants according to the needs of the organization. Meanwhile, according to Armstrong (2006) that recruitment starts from determining requirements, namely preparing job descriptions and specifications, deciding terms and conditions of employment.

Thus, the purpose of recruitment is to accept as many applicants as possible according to the qualifications of the company's needs from various sources, so that it is possible to attract candidates of the highest quality of the best (Simamora, 2006). 
International Journal of Economics, Business, and Accounting Research (IJEBAR)

Peer Reviewed - International Journal

Vol-5, Issue-1, 2021 (IJEBAR)

E-ISSN: 2614-1280 P-ISSN 2622-4771

https://jurnal.stie-aas.ac.id/index.php/IJEBAR

\section{Healthy Work Environment}

There are several obstacles in creating a healthy work environment, so that an active role of the organization is needed in evaluating the workplace environment so that the work environment can actually be created, for example managing smoking areas, prohibiting the use of hazardous substances, making a culture of disposing of garbage in the place (DeCenzo \& Robbins, 2009)

The formulation of the problem in this research are:

1. Does the Rewards and Motivation have significant effect on Internal Marketing?

2. Does the Communication have significant effect on Internal Marketing?

3. Does Development have significant effect on Internal Marketing?

4. Does Support System have significant effect on Internal Marketing?

5. Does Employee Selection have significant effect on Internal Marketing?

6. Does Employee Recruitment have significant effect on Internal Marketing?

7. Does Healthy Work Environment have significant effect on Internal Marketing?

\section{Research Method}

This research was a survey, in which the data collection using questionnaires. The survey is research taking sample from a population and as the principal means of collecting data. Understanding restricted to the survey sample survey in which part of the population is taken to represent the entire study. We create a questionnaire via Google form, and we distribute the google form link via email and private WA to Bontang Coal Terminal employees. There were 100 questionnaires that we distributed and only 84 respondents filled out the questionnaire after we downloaded the responses in sheet.

The conceptual framework this research is presented to see an overview of the relationship between variables $\mathrm{X}$ and $\mathrm{Y}$ so that it can be seen whether variable $\mathrm{X}$ influences variable $\mathrm{Y}$ or not. Refer the explanation above, the hypothesis is drawn this research as follow:

H1: Rewards and Motivation has a significant effect on Internal Marketing.

$\mathrm{H} 2$ : Communication has a significant effect on Internal Marketing.

H3: Development has a significant effect on Internal Marketing.

H4: Support System has a significant effect on Internal Marketing.

H5: Employee Selection has a significant effect on Internal Marketing.

H6: Employee Recruitment has a significant effect on Internal Marketing.

H7: Healthy Work Environment has a significant effect on Internal Marketing.

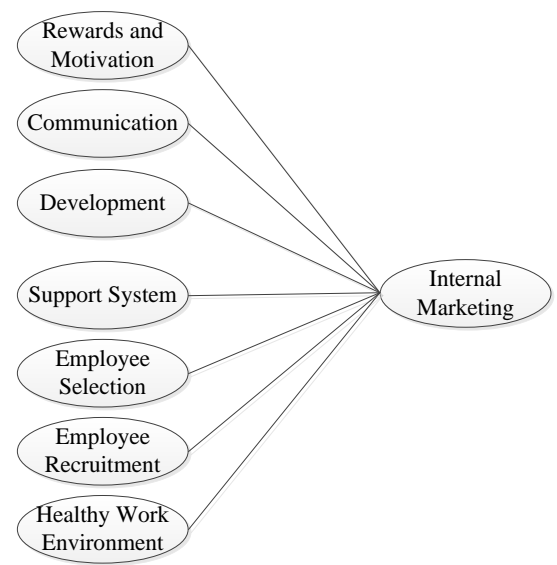

Figure 1 
International Journal of Economics, Business, and Accounting Research (IJEBAR)

Peer Reviewed - International Journal

Vol-5, Issue-1, 2021 (IJEBAR)

E-ISSN: 2614-1280 P-ISSN 2622-4771

https://jurnal.stie-aas.ac.id/index.php/IJEBAR

\section{Results and Discussion}

\section{Framework}

\subsection{Results}

The average respondent who filled out the questionnaire was male. This finding is not surprising because the average worker in mining was male. From demographic data we found that $95.2 \%$ of the respondents were male and 4.8 were female, $39.3 \%$ the age is between $36-45$ years old and $94 \%$ were already married, the average types of position that filled out the questionnaire were $29.8 \%$ foreman and $26.2 \%$ operators. Most of the education is from high school equal to $70.2 \%$, bachelor's degree is $25.0 \%$ in terms of years of work, there are $39.8 \%$ who have worked for 2125 years and $11-15$ years is $19.4 \%$

To measure of validity an item and determine an item is suitable for use or not, we tested with the results of the correlation coefficient. The validity test used is the Bivariate Pearson correlation (Pearson Moment Product) and the Corrected Item-Total Correlation by PASW Statistics 18 with df 30. From the results of the analysis, the item score can be obtained with the total score. Then we compare this value with the $r$ table value. $r$ table is looked for at $5 \%$ significance with a two-tailed test with $\mathrm{N}=32$ then the value of $\mathrm{df}=30$ is obtained, if it is seen from the list of $r$ table by (Junaidi, 2010) with df 30 , then the number is 0.3494 . If the $r$ value of the analysis results is less than $(<) \mathrm{r}$ table, it can be concluded that these items are not significantly correlated with the total score or are declared invalid and must be excluded or corrected.

\section{Item Validity}

Internal Marketing Variables have 7 indicators, and in each of these indicators has 3 question items, totaling 21 questions. The results of the $r$ value are more than $(>) r$ table, it can be concluded that these items have a significant correlation with the total score or are declared valid.

\begin{tabular}{|c|c|c|c|c|}
\hline No & Item & $r$ count & $r$ table & Interpretation \\
\hline 1 & IMRM1 & 0.449 & 0.349 & Valid \\
\hline 2 & IMRM2 & 0.572 & 0.349 & Valid \\
\hline 3 & IMRM3 & 0.462 & 0.349 & Valid \\
\hline 4 & IMC1 & 0.467 & 0.349 & Valid \\
\hline 5 & IMC2 & 0.681 & 0.349 & Valid \\
\hline 6 & IMC3 & 0.554 & 0.349 & Valid \\
\hline 7 & IMD1 & 0.626 & 0.349 & Valid \\
\hline 8 & IMD2 & 0.755 & 0.349 & Valid \\
\hline 9 & IMD3 & 0.475 & 0.349 & Valid \\
\hline 10 & IMSS1 & 0.755 & 0.349 & Valid \\
\hline 11 & IMSS2 & 0.746 & 0.349 & Valid \\
\hline 12 & IMSS3 & 0.759 & 0.349 & Valid \\
\hline 13 & IMES1 & 0.819 & 0.349 & Valid \\
\hline 14 & IMES2 & 0.764 & 0.349 & Valid \\
\hline 15 & IMES3 & 0.674 & 0.349 & Valid \\
\hline
\end{tabular}


International Journal of Economics, Business, and Accounting Research (IJEBAR) Peer Reviewed - International Journal

Vol-5, Issue-1, 2021 (IJEBAR)

E-ISSN: 2614-1280 P-ISSN 2622-4771

https://jurnal.stie-aas.ac.id/index.php/IJEBAR

\begin{tabular}{|c|l|l|l|l|}
\hline $\mathbf{1 6}$ & IMER1 & 0.455 & 0.349 & Valid \\
\hline $\mathbf{1 7}$ & IMER2 & 0.757 & 0.349 & Valid \\
\hline $\mathbf{1 8}$ & IMER3 & 0.637 & 0.349 & Valid \\
\hline $\mathbf{1 9}$ & IMHW1 & 0.663 & 0.349 & Valid \\
\hline $\mathbf{2 0}$ & IMHW2 & 0.721 & 0.349 & Valid \\
\hline $\mathbf{2 1}$ & IMHW3 & 0.713 & 0.349 & Valid \\
\hline
\end{tabular}

\section{Reliability}

From the results of the validity test, the items that are valid are then analyzed for their reliability, and from the results of the analysis an Alpha value is obtained of 0.929 . The critical $r$ value (2tiled) at $5 \%$ significance with $\mathrm{n}=32(\mathrm{df}=\mathrm{n}-2=30)$, can be 0.349 , it can be concluded that the items of the research instrument are reliable or very high reliability, namely $>0.80$.

Table 2 Item-Total Statistics Internal Marketing

\begin{tabular}{|l|c|c|c|c|}
\hline & $\begin{array}{c}\text { Scale Mean } \\
\text { if Item } \\
\text { Deleted }\end{array}$ & $\begin{array}{c}\text { Scale } \\
\text { Variance if } \\
\text { Item } \\
\text { Deleted }\end{array}$ & $\begin{array}{c}\text { Corrected } \\
\text { Item-Total } \\
\text { Correlation }\end{array}$ & $\begin{array}{c}\text { Cronbach's } \\
\text { Alpha if Item } \\
\text { Deleted }\end{array}$ \\
\hline IMRM1 & 83.2813 & 56.144 & .515 & .927 \\
\hline IMRM2 & 83.1563 & 55.943 & .613 & .925 \\
\hline IMRM3 & 83.2188 & 54.434 & .516 & .928 \\
\hline IMC1 & 83.0938 & 56.862 & .501 & .927 \\
\hline IMC2 & 83.0000 & 55.484 & .697 & .924 \\
\hline IMC3 & 83.2500 & 57.097 & .589 & .926 \\
\hline IMD1 & 83.0000 & 54.710 & .537 & .927 \\
\hline IMD2 & 83.2500 & 54.194 & .716 & .923 \\
\hline IMD3 & 83.2500 & 55.226 & .459 & .929 \\
\hline IMSS1 & 82.8750 & 55.274 & .647 & .925 \\
\hline IMSS2 & 82.8750 & 55.339 & .639 & .925 \\
\hline IMSS3 & 82.9063 & 53.830 & .764 & .922 \\
\hline IMES1 & 83.0938 & 54.862 & .785 & .923 \\
\hline IMES2 & 83.0938 & 55.055 & .757 & .923 \\
\hline IMES3 & 83.1563 & 56.394 & .648 & .925 \\
\hline IMER1 & 83.1563 & 56.846 & .350 & .931 \\
\hline IMER2 & 82.8125 & 55.060 & .656 & .924 \\
\hline IMER3 & 82.9688 & 55.838 & .549 & .926 \\
\hline IMHW1 & 83.1875 & 54.157 & .656 & .924 \\
\hline IMHW2 & 82.9688 & 54.934 & .596 & .925 \\
\hline IMHW3 & 82.7813 & 54.951 & .664 & .924 \\
\hline
\end{tabular}

\section{Convergent Validity}


International Journal of Economics, Business, and Accounting Research (IJEBAR)

Peer Reviewed - International Journal

Vol-5, Issue-1, 2021 (IJEBAR)

E-ISSN: 2614-1280 P-ISSN 2622-4771

https://jurnal.stie-aas.ac.id/index.php/IJEBAR

Convergent validity to see two different instruments measuring the same concept that show a high correlation. Indicators that have convergent validity are having an outer loading factor above 0.70 , but the loading factor value of 0.50-0.60 can still be tolerated with a t-statistic value above 1.96 or a $\mathrm{p}$-value $<0.05$. If we see the figure 1 from the result of PLS algorithm showed that the loading factor value more than 0.70 so this indicate the convergent validity is higher.

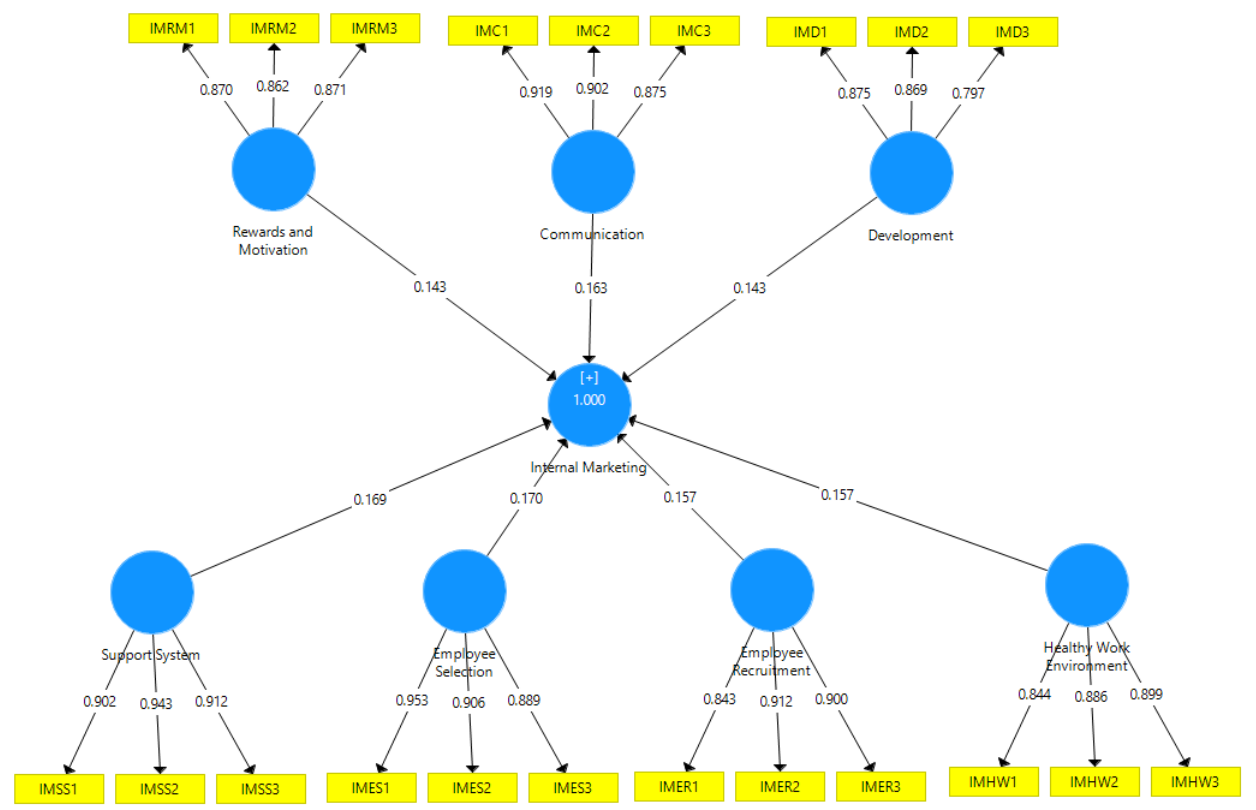

Figure 1 PLS Algorithm

Another way to assess the validity is to look at the Average Variance Extracted (AVE) value. If the AVE value is more than 0.50 then it can indicate construct of validity, which means that the latent variable explains more than half of the variance of the indicator. After tested the value result of AVE each variable is more than 0.50 that indicated the all variable is valid

Table 3 Average Variance Extracted (AVE)

\begin{tabular}{|l|c|c|}
\hline \multicolumn{1}{|c|}{ Variables } & AVE & Remark \\
\hline Rewards and Motivation & 0.753 & Valid \\
\hline Communication & 0.808 & Valid \\
\hline Development & 0.719 & Valid \\
\hline Support System & 0.845 & Valid \\
\hline Employee Selection & 0.840 & Valid \\
\hline Employee Recruitment & 0.784 & Valid \\
\hline Healthy Work Environment & 0.768 & Valid \\
\hline Internal Marketing & 0.647 & Valid \\
\hline
\end{tabular}

\section{Reliability Test}

Composite reliability and Cronbach alpha are used to test the value of reliability or reliability between the indicators of the constructs that make it up. The composite reliability and Cronbach alpha values are said to be good, if the value is above 0.70 is recommended, but the factor value 
International Journal of Economics, Business, and Accounting Research (IJEBAR)

Peer Reviewed - International Journal

Vol-5, Issue-1, 2021 (IJEBAR)

E-ISSN: 2614-1280 P-ISSN 2622-4771

https://jurnal.stie-aas.ac.id/index.php/IJEBAR

of 0.50-0.60 can still be tolerated. In other words, good composite reliability and Cronbach alpha values indicate that discriminant validity has been achieved.

Table 4 Cronbach's Alpha and Composite Reliability

\begin{tabular}{|l|r|r|c|}
\hline \multicolumn{1}{|c|}{ Variables } & $\begin{array}{c}\text { Cronbach's } \\
\text { Alpha }\end{array}$ & $\begin{array}{c}\text { Composite } \\
\text { Reliability }\end{array}$ & Remark \\
\hline Rewards and Motivation & 0.836 & 0.901 & Reliable \\
\hline Communication & 0.881 & 0.926 & Reliable \\
\hline Development & 0.803 & 0.884 & Reliable \\
\hline Support System & 0.908 & 0.942 & Reliable \\
\hline Employee Selection & 0.905 & 0.940 & Reliable \\
\hline Employee Recruitment & 0.862 & 0.916 & Reliable \\
\hline Healthy Work Environment & 0.849 & 0.909 & Reliable \\
\hline Internal Marketing & 0.973 & 0.975 & Reliable \\
\hline
\end{tabular}

\section{Inner Model Evaluation}

In assessing the model, it starts by looking at the R-square value for each dependent latent variable. Table 5 shows the R-Square estimation results obtained by processing data in SmartPLS. In this study, the structural model was evaluated by considering the R-square (R2) and stone-Geisser's Q2 (predictive relevance model). Q2 (predictive relevance model) which measures how good the observation value that was generated by the model. Q2 is based on the coefficient of determination (R2) of all endogenous variables. The magnitude of Q2 has a range value of $0<\mathrm{Q} 2<1$, the closer to the value of 1 , the better the model as shown table below:

Table 5 R Square

\begin{tabular}{|l|c|c|}
\hline Variable & R Square & $\begin{array}{c}\text { R Square } \\
\text { Adjusted }\end{array}$ \\
\hline Internal Marketing & 1.000 & 1.000 \\
\hline
\end{tabular}

\subsection{Discussion}

Hypothesis test parameters use the comparison of the $\mathrm{T}$ value, if the value of $\mathrm{T}$ count $>$ from $\mathrm{T}$ table (1.96) or $\mathrm{P}$ value $<0.05$, then $\mathrm{H}_{0}$ is rejected and $\mathrm{H}_{1}$ is accepted. The results of $\mathrm{T}$ table and $\mathrm{P}$ value from bootstrapping to see the relationship between the influence of variables. From the results of the PLS bootstrapping, it can be seen from table 6 with the following results:

Table 5 Influence of Exogenous (X) and Endogenous (Y)

\begin{tabular}{|l|c|c|c|c|r|}
\hline \multicolumn{1}{|c|}{ Variable } & $\begin{array}{c}\text { Original } \\
\text { Sample } \\
(\mathbf{O})\end{array}$ & $\begin{array}{c}\text { Sample } \\
\text { Mean } \\
(\mathbf{M})\end{array}$ & $\begin{array}{c}\text { Standard } \\
\text { Deviation } \\
\text { (STDEV) }\end{array}$ & $\begin{array}{c}\text { T Statistics } \\
(\mid \mathbf{O} \text { (STDEV|) }\end{array}$ & P Values \\
\hline $\begin{array}{l}\text { Rewards and Motivation } \\
\text {-> Internal Marketing }\end{array}$ & 0.143 & 0.142 & 0.010 & 14.696 & 0.000 \\
\hline $\begin{array}{l}\text { Communication -> } \\
\text { Internal Marketing }\end{array}$ & 0.163 & 0.162 & 0.009 & 18.259 & 0.000 \\
\hline
\end{tabular}

International Journal of Economics, Business, and Accounting Research (IJEBAR) Page 99 
International Journal of Economics, Business, and Accounting Research (IJEBAR)

Peer Reviewed - International Journal

Vol-5, Issue-1, 2021 (IJEBAR)

E-ISSN: 2614-1280 P-ISSN 2622-4771

https://jurnal.stie-aas.ac.id/index.php/IJEBAR

\begin{tabular}{|l|r|r|r|r|r|}
\hline $\begin{array}{l}\text { Development -> Internal } \\
\text { Marketing }\end{array}$ & 0.143 & 0.144 & 0.008 & 16.905 & 0.000 \\
\hline $\begin{array}{l}\text { Support System -> } \\
\text { Internal Marketing }\end{array}$ & 0.169 & 0.169 & 0.009 & 18.517 & 0.000 \\
\hline $\begin{array}{l}\text { Employee Selection -> } \\
\text { Internal Marketing }\end{array}$ & 0.170 & 0.169 & 0.009 & 19.686 & 0.000 \\
\hline $\begin{array}{l}\text { Employee Recruitment - } \\
\text { Internal Marketing }\end{array}$ & 0.157 & 0.156 & 0.011 & 14.454 & 0.000 \\
\hline $\begin{array}{l}\text { Healthy Work } \\
\text { Environment -> Internal } \\
\text { Marketing }\end{array}$ & 0.157 & 0.157 & 0.007 & 21.927 & 0.000 \\
\hline
\end{tabular}

The bootstrapping results diagram can be seen in Figure 2 below:

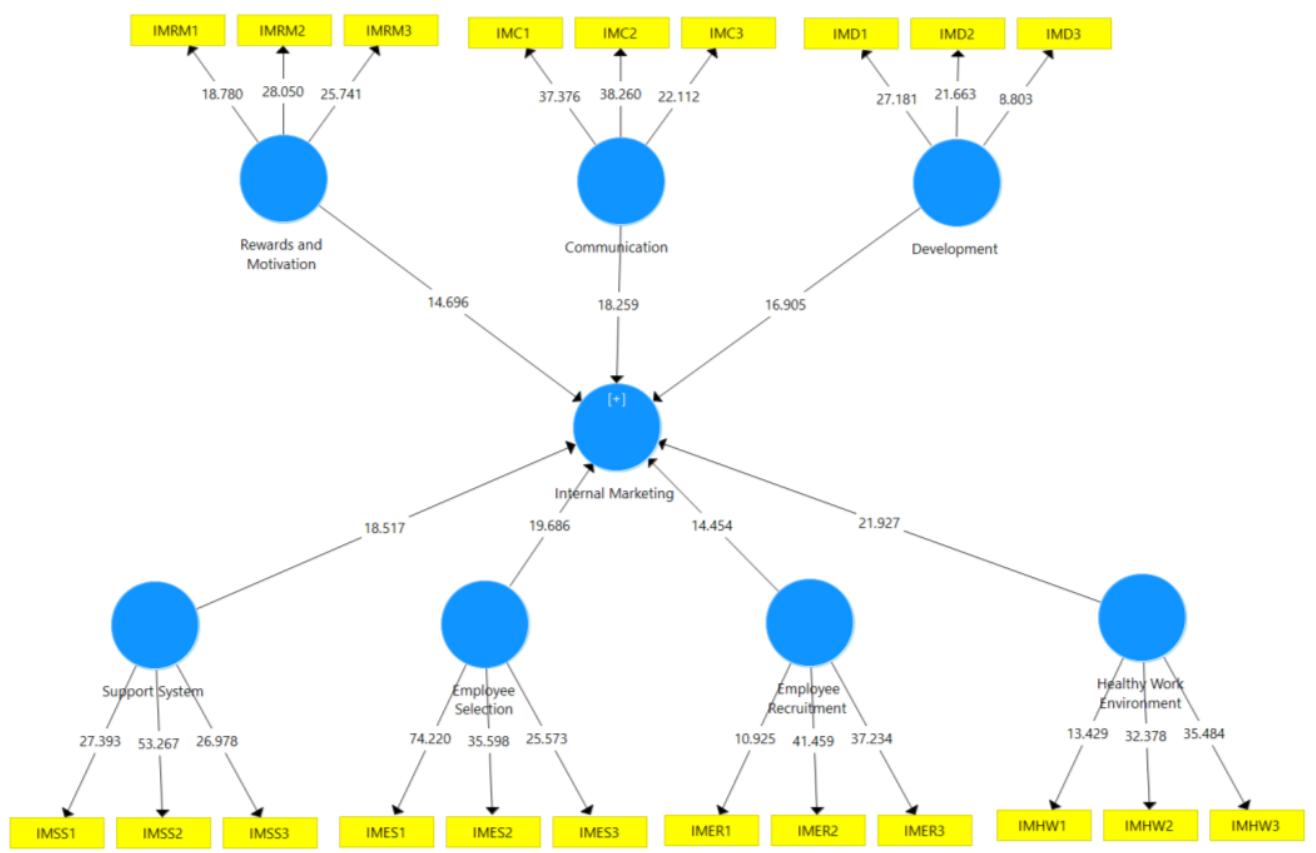

Figure 2 PLS Bootstrapping

The conclusions on the hypothesis testing on each exogenous and endogenous variable base on $\mathrm{T}$ table or P value are as follows:

H1: The effect of Rewards and Motivation on Internal Marketing through a path coefficient of 0.143 and $\mathrm{T}$-statistic value is 14.696 and $\mathrm{P}$ value is 0.000 . The T-statistic value is greater than the $\mathrm{T}$ table (1.96), while the $\mathrm{P}$ value is less than $<0.05$. So, it can be concluded that Rewards and Motivation have a positive significant effect on Internal Marketing.

$\mathrm{H} 2$ : The effect of Communication on Internal Marketing through a path coefficient of 0.163 and T-statistic value is 18.259 and $\mathrm{P}$ value is 0.000 . The T-statistic value is greater than the $\mathrm{T}$ table (1.96), while the $\mathrm{P}$ value is less than $<0.05$. So, it can be concluded that Communication has a positive significant effect on Internal Marketing.

H3: The effect of Development on Internal Marketing through a path coefficient of 0.143 and T-statistic value is 16.905 and $\mathrm{P}$ value is 0.000 . The T-statistic value is greater than the $\mathrm{T}$ 
table (1.96), while the $\mathrm{P}$ value is less than $<0.05$. So, it can be concluded that Development has a positive significant effect on Internal Marketing.

H4: The effect of Support System on Internal Marketing through a path coefficient of 0.169 and T-statistic value is 18.517 and $\mathrm{P}$ value is 0.000 . The T-statistic value is greater than the T table (1.96), while the $\mathrm{P}$ value is less than $<0.05$. So, it can be concluded that Support System have a positive significant effect on Internal Marketing.

H5: The effect of Employee Selection on Internal Marketing through a path coefficient of 0.170 and T-statistic value is 19.686 and $\mathrm{P}$ value is 0.000 . The T-statistic value is greater than the $\mathrm{T}$ table (1.96), while the $\mathrm{P}$ value is less than $<0.05$. So, it can be concluded that Employee Selection have a positive significant effect on Internal Marketing.

H6: The effect of Employee Recruitment on Internal Marketing through a path coefficient of 0.157 and $\mathrm{T}$-statistic value is 14.454 and $\mathrm{P}$ value is 0.000 . The T-statistic value is greater than the $\mathrm{T}$ table (1.96), while the $\mathrm{P}$ value is less than $<0.05$. So, it can be concluded that Employee Recruitment have a positive significant effect on Internal Marketing.

H7: The effect of Healthy Work Environment on Internal Marketing through a path coefficient of 0.157 and T-statistic value is 21.927 and $\mathrm{P}$ value is 0.000 . The T-statistic value is greater than the $\mathrm{T}$ table (1.96), while the $\mathrm{P}$ value is less than $<0.05$. So, it can be concluded that Healthy Work Environment have a positive significant effect on Internal Marketing.

\section{Conclusion}

The results of data analysis state that Rewards and Motivation, Communication, Development, Support System, Employee Selection, Employee Recruitment, and Healthy Work Environment have a positive significant effect on Internal Marketing. This means that Rewards and Motivation, Communication, Development, Support System, Employee Selection, Employee Recruitment, and a Healthy Work Environment in this case in the port division of Bontang Coal Terminal can determine significant success in Internal Marketing. These results indicate that the better the Internal Marketing in the port division, the more employee will be trust in the company. This means allowing employees to perform services effectively, and fulfill promises made to customers.

\section{Suggestions}

The job of internal marketing is to recruit, train and motivate employees who can serve customers well. Internal marketing takes place at two levels, the first functions as sales force marketing, advertising, customer service product management, marketing research. The researcher realizes that this research still has many shortcomings, one of which is the lack of problems, the researcher also realizes that there are many other variables that affect Internal Marketing that have not been examined in this study. Therefore, the researcher hopes that if there are other researchers who carry out research with a similar theme, what needs to be considered is to examine deeper problems and other things that need to be considered for further research.

\section{Reference}

Armstrong, M. (2006). A Handbook of Human Resource Management Practice. In British Library Cataloguing in Publication Data (10th ed.). Kogan Page. https://doi.org/10.1017/CBO9781139062381.069

Ballantyne, D. (2004). A Relationship Meditiated Theory of Internal Marekting. In Swedish School of Economic Business Administration. 
International Journal of Economics, Business, and Accounting Research (IJEBAR)

Peer Reviewed - International Journal

Vol-5, Issue-1, 2021 (IJEBAR)

E-ISSN: 2614-1280 P-ISSN 2622-4771

https://jurnal.stie-aas.ac.id/index.php/IJEBAR

Burke, R., \& Wilcox, D. (2006). Characteristics of Effective Employee Performance Review and Development Interviews. Personnel Psychology, 22, 291-305. https://doi.org/10.1111/j.1744-6570.1969.tb00334.x

Chun-Cheng, C., \& Hung, S. (2008). Goal orientation, service behavior and service performance. Asia Pacific Management Review, 13(2), 513-529.

DeCenzo, D. A., \& Robbins, S. P. (2009). Fundamentals of Human Resource Management (10th Edition) By David A. DeCenzo, Stephen P. Robbins - Wiley (2009) (10th ed.). John Wiley \& Sons, Inc. http://www.wiley.com/go/permissions

Elsamen, A. A., \& Alshurideh, M. (2012). The Impact of Internal Marketing on Internal Service Quality: A Case Study in a Jordanian Pharmaceutical Company. 7(19), 84-95. https://doi.org/10.5539/ijbm.v7n19p84

Gronroos, C. (1994). From Marketing Mix to Relationship Marketing: Towards a Paradigm Shift in Marketing. Management Decision. In (C MCB University Press Limited (Vol. 32).

Junaidi. (2010). Tabel $r$ (Koefisien Korelasi Sederhana). https://junaidichaniago.files.wordpress.com/2010/05/tabel-r.pdf

Kaner, S., Lind, L., Toldi, C., Fisk, S., \& Berger, D. (2007). Facilitator's Guide to Participatory Decision-making, Second Edition. 341.

Kotler, P, \& Armstrong, G. (2008). Prinsip-prinsip Pemasaran, Edisi Kedua Belas (pp. 1-440). Erlangga.

Kotler, Philip, \& Keller, K. L. (2009). Prinsip-Prinsip Pemasaran. Erlangga.

Kumar, J. (2010). Marketing of Hospitality and Tourism Services.

Larsson, R., Brousseau, K. R., Kling, K., \& Sweet, P. L. (2007). Building motivational capital through career concept and culture fit: The strategic value of developing motivation and retention. Career Development International, 12(4), 361-381. https://doi.org/10.1108/13620430710756753

Lovelock, C., \& Wright, L. (2000). Book Review: Principles of Service Marketing and Management. Journal of Vacation Marketing, 6(3), 281-283. https://doi.org/10.1177/135676670000600309

Luthans, F. (2009). Organizational Behavior. In Hospital Administration. https://doi.org/10.5005/jp/books/10358_23

Raymond, N. A., John, H. R., M.Barry, G., \& Patrick, W. M. (2016). Strategic Human Resource Management Gaining a Competitive Advantage. In Book.

Robbins, S. P., \& Coulter, M. (2018). Management, 14th Edition (14th ed.). Pearson Education Limited.

Roberts-lombard, M. (2010). Employees as customers An internal marketing study of the Avis car rental group in South Africa. African Journal of Business Management, 4(4), 62-372.

Sarker, M. A. R., \& Ashrafi, D. M. (2018). The relationship between internal marketing and employee job satisfaction: A study from retail shops in Bangladesh. Journal of Business and Retail Management Research, 12(3), 149-159. https://doi.org/10.24052/jbrmr/v12is03/art-13

Simamora, H. (2006). Manajemen Sumber Daya Manusia (Edisi 3).

Tansey, L., McHugh, E. \& McGrath, E. (2004). The Role of Internal Marketing in the Motivation of High Contact Service Employees. Galway:National University of Ireland, $1-19$.

Ting, S. C. (2011). The effect of internal marketing on organizational commitment: job involvement and job satisfaction as mediators. Educational Administration Quarterly,

International Journal of Economics, Business, and Accounting Research (IJEBAR) Page 102 
International Journal of Economics, Business, and Accounting Research (IJEBAR)

Peer Reviewed - International Journal

Vol-5, Issue-1, 2021 (IJEBAR)

E-ISSN: 2614-1280 P-ISSN 2622-4771

https://jurnal.stie-aas.ac.id/index.php/IJEBAR

47(2), 353-382.

Tony, P., \& Ioanna, D. (2003). Change management: the role of internal communication and employee development. Corporate Communications: An International Journal, 8(4), 268277. https://doi.org/10.1108/13563280310506430 